\title{
OLAHAN SAYURAN MENJADI ES KRIM NABATI PADA IBU-IBU RT 03/04 DIKELURAHAN TAMALANREA JAYA
}

\author{
Khaeriyah Darwis, St. Khadijah Yahya Hiola \\ Fakultas Pertanian, Universitas Muhammadiyah Makassar \\ Email : khaeriyah.darwis@gmail.com
}

\begin{abstract}
This vegetable processing training aims to build the entrepreneurial spirit of RT 03/04 with the utilization of processed red spinach and broccoli vegetables which if developed over the long term will foster a productive economy that can increase family income. In addition, it is hoped that later, ladies and gentlemen, RT 03/04 Tamalanrea Jaya Village is able to form a Trade Business that produces Broccoli and Red Spinach Vegetable ice cream. Community service activities are carried out with training methods in practice and theory. For two days, the community members were invited to understand the purpose, benefits and application of healthy processed broccoli vegetables as a nutritious processed food and economic value. Presentation of learning material related to the importance of community empowerment through an independent learning process, this group is carried out in accordance with the material, goals and practical benefits of each theme. At the last session, this community service activity was presented with a demonstration of cooking food, processing broccoli and red spinach vegetables into healthy, practical ice cream and liked by all people. The activity of processing broccoli and red spinach vegetables as raw materials to obtain these types of food is done by demonstration method while providing explanations that must be mastered when going to process red spinach and broccoli into healthy food for the family, and economic value.
\end{abstract}

Keyword : Broccoli Vegetables, Red Spinach, Vegetable Ice Cream

\section{PENDAHULUAN}

Kondisi Umum Kelurahan

\section{Tamalanrea Jaya}

Banyak orang yang menyatakan sangat menyukai es krim. Namun, sebagian merasa khawatir akan naiknya kondisi berat badan dan langsung menghindari dessert yang lezat ini. Banyak kalangan perempuan dan ibu rumah tangga menghentikan pemberian es krim untuk anak-anak mereka dengan alasan "dapat merusak gigi" atau "nanti terkena flu". Namun, berdasarkan sebuah penelitian terbaru, ternyata ada sejumlah manfaat es krim yang sangat baik untuk kesehatan.

\section{Kaya Kalsium}

Es krim dibuat dengan produk susu yang kaya akan kalsium dan nutrisi 
untuk memperkuat tulang dan sistem saraf.

menaikkan energi tubuh.

\section{Menurunkan Berat Badan}

\section{Melindungi Gigi dan Gusi}

Es Krim ternyata dapat membantu Kalsium yang terkandung dalam es krim juga berguna untuk melindungi gigi dan membangun gusi yang kuat. Jadi, mulai sekarang pikirkan lagi sebelum berhenti memberi anak Anda es krim.

menurunkan berat badan.
Mengkonsumsi sesuatu yang dingin akan meningkatkan suhu tubuh dan membakar kalori serta lemak.

\section{Mengandung Protein}

Tubuh membutuhkan protein setiap hari untuk membangun dan

\section{Mengurangi Peradangan}

Cokelat dalam es krim juga bermanfaat bagi tubuh. es krim jenis ini kaya akan flavonoid yang mengurangi peradangan arteri jantung. Dark chocolate memiliki flavonoid yang melindungi arteri jantung dari kelelahan.

\section{Kaya Vitamin}

Satu sendok es krim memiliki banyak kandungan vitamin $\mathrm{A}, \mathrm{D}, \mathrm{K}$ dan B12. Vitamin A baik untuk kesehatan mata, vitamin D menyerap kalsium dan nutrisi dari makanan dan menyimpannya di ginjal. Vitamin $\mathrm{K}$ meningkatkan aliran darah dalam tubuh dan membuka sel darah tersumbat. Vitamin B12 meningkatkan memori dan memperbaiki jaringan otot. Sesendok es krim dapat menyediakan jumlah protein yang cukup untuk satu hari yang aktif.

\section{Rendah Lemak}

Es krim yang dibuat dengan bahan rendah lemak seperti susu skim memiliki manfaat kesehatan yang lebih banyak. Jika Anda khawatir tentang masalah kenaikan berat badan, hal tersebut tidak akan terjadi.

\section{Situasi RT 03/04 Tamalanrea Jaya}

Kelurahan Tamalanrea Jaya yang berkembang dengan jenis-jenis perumahan memiliki makna positif bagi perkembangan wilayah namun di sisi lain juga berpengaruh terhadap kondisi pengairan dan masalah peresapan air, 
sehingga di wilayah-wilayah tertentu seringkali terjadi banjir. Dengan beberapa jenis perumahan dibangun di sekitar lahan desa yang semula berupa tanah pertanian, rawa, dan tanah yang tidak terpelihara kini menjadi wilayah yang penuh dengan fasilitas-fasilitas publik dan jasa sehingga penduduk menjadi semakin berkembang. Perkembangan penduduk juga oleh adanya fasilitas pendidikan khususnya perguruan tinggi dan sekolah tinggi yang lokasinya relatif dengan perumahan. Kondisi ini menyebabkan berkembangnya sistem sosial dan ekonomi masyarakat sekitarnya, dengan adanya pemondokan, kontrak atau sewa rumah, layanan jasa, layanan kuliner, serta minimarket yang dibangun di wilayah Tamalanrea Jaya.

\section{Dinamika Sosial Ekonomi Warga} RT 03/04 Kelurahan Tamalanrea Jaya

Kelurahan Tamalanrea Jaya memiliki keberagaman penduduk. Maka dapat dipastikan perubahan kependudukan juga semakin berusia dewasa, tua atau lansia, dengan status ibu rumah tangga yang waktunya kebanyakan dihabiskan dirumah dan mengikuti kegiatan Majelis Taklim. Kegiatan ibu-ibu majelis taklim ini meliputi kegiatan pengajian dan kegiatan sosial, kerja bakti, pertemuan rutin PKK dan pertemuan antar RT. Dan terkini majelis taklim ini sudah membentuk kelompok tani wanita. Kebutuhan akan peningkatan kualitas kehidupan yang sinergis dengan ketahanan pangan, gizi dan lingkungan yang tertata, bersih dan mencukupi kebutuhan hidup dan keluarga tampaknya semakin dibutuhkan oleh ibu-ibu rumah tangga di wilayah perumahan ini. Oleh karena itu kegiatan PPM oleh dosen-dosen dan mahasiswa Faperta Unismuh ini diperuntukkan untuk ibu-ibu rumah tangga sekitar 10 orang yang diasumsikan memiliki kemauan yang keras untuk mengembangkan jiwa kewirausahaan dibidang pertanian khususnya pengolahan pangan komoditi sayur brokoli dan bayam merah. Hal ini menjadi pilihan karena ibu-ibu ini memiliki hobi memasak, pengolahan sayur yang mudah.

\section{Permasalahan yang Dihadapi}

(1) Masih adanya kesulitan bagi warga masyarakat untuk menciptakan 
kondisi perumahan yang bersih, sehat dan bermakna bagi kegiatan-kegiatan usaha produktif.

(2) Masih adanya warga masyarakat yang belum memiliki pengetahuan dan keterampilan tertentu guna mengisi kegiatan dalam kehidupan sehari-hari secara berkualitas.

(3) Masih adanya warga masyarakat yang memiliki kemauan, kemampuan dan keterampilan usaha namun keterbatasan modal usaha, kemampuan manajemen usaha yang menguntungkan.

(4) Belum optimal dan terfokusnya pembinaan bagi para pelaku usaha kecil yang ada dikawasan perumahan.

(5) Belum berkembangnya kemampuan wirausaha dalam melakukan peningkatan kualitas hidup bagi diri, keluarga dan masyarakat sekitarnya khususnya warga masyarakat yang tidak melakukan pekerjaan di luar rumah misalnya ibu rumah tangga ataupun pengangguran.

SOLUSI DAN TARGET LUARAN YANG DICAPAI

(1) Membangun gerakan mencintai tubuh dengan mengkonsumsi makanan- makanan yang sehat dan diproduksi sendiri.

(2) Membantu warga untuk memiliki pengetahuan, keterampilan tertentu sebagai bagian dari usaha produktif dan peningkatan kualitas kehidupannya setidaknya bagi pilihan makanan yang sehat dan bergizi.

(3) Membangun jiwa $\begin{array}{llll}\text { kewirausahaan ibu-ibu RT } & \text { 03/04 }\end{array}$ dengan pemanfaatan olahan pangan sayur brokoli yang jika dikembangkan hingga jangka panjang akan menumbuhkan ekonomi produktif yang mampu menambah pendapatan keluarga. Selain itu, diharapkan nanti Ibu-Ibu RT 03/04 mampu membentuk Usaha Dagang yang memproduksi Es Krim Brokoli dan Es krim Bayam Merah

\section{METODE PELAKSANAAN}

Pelaksanaan Kegiatan Pengabdian ini di Kelurahan Tamalanrea Jaya RT 03/04 pada tanggal 21 Agustus 2018. Pengusul terdiri atas 2 orang yakni Dosen Agribisni dan Dosen Teknologi Pengolahan. Mitra terdiri dari 10 orang, dan melibatkan mahasiswa. Agar kegiatan ini menjadi efektif, tercapai 
tujuan dan memiliki makna dan manfaat bagi para peserta pelatihan, maka kegiatan yang terbagi ke dalam beberapa tahap ini dilakukan dengan metode yang berbeda-beda. Kegiatan pengabdian pada masyarakat RT 03/04 dilakukan dengan metode pelatihan secara praktek dan teori. Selama dua hari berturut-turut warga masyarakat diajak untuk memahami tujuan, manfaat dan penerapan olahan brokoli dan bayam merah yang sehat sebagai bahan olahan makan yang bergizi dan bernilai ekonomi.

Penyajian materi pembelajaran yang berkaitan dengan pentingnya pemberdayaan masyarakat melalui proses belajar mandiri, kelompok ini dilakukan sesuai dengan materi, tujuan dan manfaat praktis dari masingmasing tema.

Pada sesi terakhir, kegiatan pengabdian pada masyarakat ini disajikan demonstrasi memasak makanan, mengolah sayur brokoli dan bayam merah menjadi es krim yang sehat, praktis dan disukai oleh semua kalangan. Kegiatan mengolah sayur brokoli sebagai bahan baku untuk memperoleh jenis-jenis pangan ini dilakukan dengan metode demonstrasi sambil memberikan penjelasanpenjelasan yang harus dikuasai ketika akan mengolah sayur brokoli menjadi pangan yang sehat bagi keluarga, dan bernilai ekonomis.

\section{HASIL DAN PEMBAHASAN}

\section{Pembahasan Kegiatan Pelatihan}

a. Kegiatan pengabdian pada masyarakat dengan pokok materi mengenai pelatihan olahan sayur brokoli dilaksanakan dengan beberapa tahap. Pada tahap pertama adalah rekrutmen peserta dengan melalui para ketua RT dimintai daftar nama peserta yang sekiranya mau, mampu mengikuti kegiatan secara penuh dan terlebih dapat mengembangkan pengetahuan dan keterampilannya pasca pelatihan secara berkesinambungan. Sistem rekrumen ini sangat lazim dilakukan untuk mengawali berbagai kegiatan program pemberdayaan masyarakat.

b. Dengan bermitra kerja bersama nara sumber yang kompeten, kegiatan pengabdian pada masyarakat ini menjadi kegiatan lebih menyenangkan, mudah diterima dan berdampak pada 
peningkatan motivasi untuk melakukan usaha pengolahan sayur brokoli dan bayam merah, minimal untuk memenuhi kebutuhan diri dan keluarganya saja.

c. Penyajian pengetahuan dan pelatihan sayur brokoli dan bayam merah dengan menggunakan metode ceramah, tanya jawab yang berkaitan dengan sayur brokoli dan bayam merah serta praktek pengolahan pangan yang baik. Metode demonstrasi dan menunjukkan pengolahan sayur brokoli dan bayam merah menjadi es krim sayur brokoli dan bayam merah dalam perkembangannya secara konkrit, termasuk pemilihan sayur yang baik dan segar, cara mengolahnya secara tepat.

d. Penyajian bentuk olahan masakan siap saji dengan bahan dasar sayur brokoli dan bayam merah berupa es krim digunakan dengan metode ceramah, demonstrasi cara membuat es krim dengan bahan sayur brokoli dan bayam merah dilengkapi dengan tanya jawab dan kesempatan membuat es krim bersama dan mencicipi hasil masakan secara bersama dengan beberapa resep masakan praktis sesuai permintaan peserta.

e. Pelatihan kewirasahaan selama 1 hari (teori dan praktek). Dalam waktu sekitar seminggu setelahnya tim pelaksana yang ada di lapangan diminta melakukan kunjungan ke rumah para peserta untuk mengumpulkan informasi-informasi penting berkaitan dengan masalah, kesulitan dalam pengolahan sayur brokoli dan bayam merah.

Pendampingan oleh tim pelaksana di lapangan ini menjadi awal dari pendampingan sesudahnya. Kegiatan pendampingan dilakukan selama sekitar 2 jam dengan mengumpulkan para peserta setelah seminggu usai pelatihan. Model pendampingan dilakukan dengan metode curah pendapat berbagai informasi demi perkembangan bersama. Ada kemungkinan dalam pendampingan akan dilakukan reedukasi atau merefresh kembali pengetahuannya. 


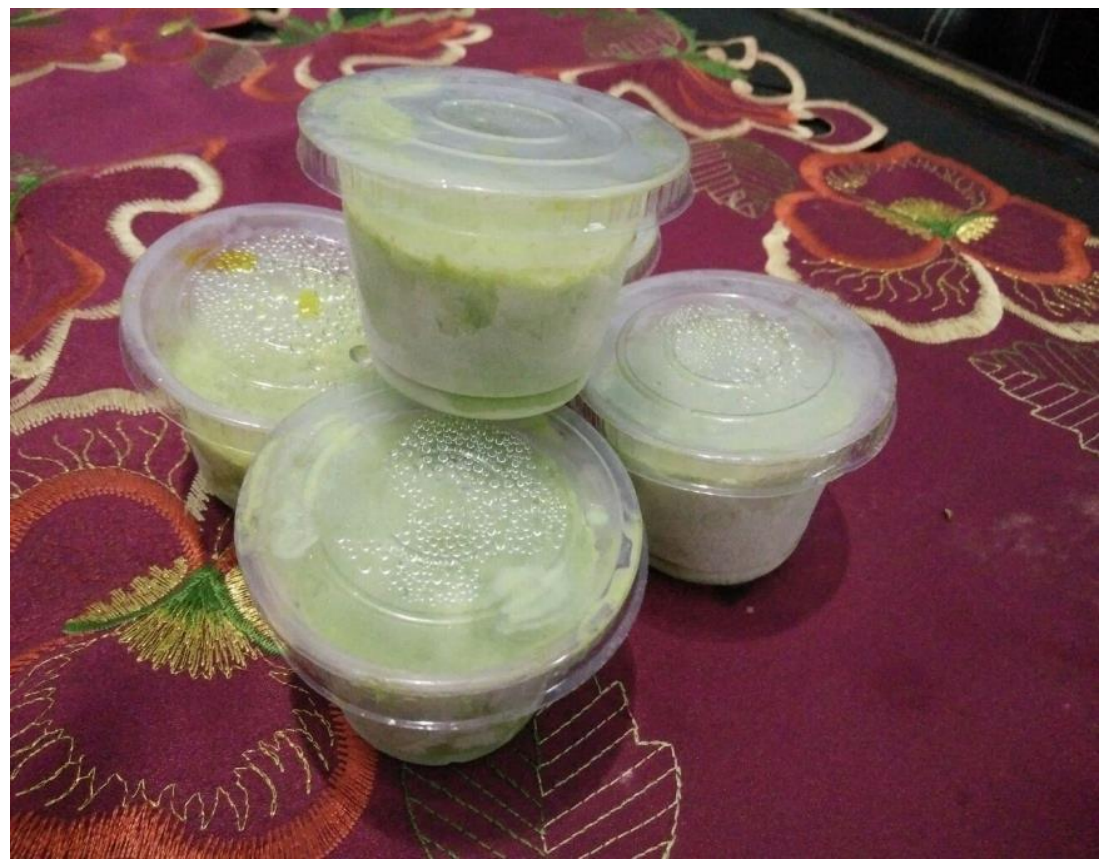

Produk Sayuran menjadi Es Krim Nabati

\section{SIMPULAN}

Peningkatan kualitas hidup melalui pelatihan pengolahan sayur brokoli dan bayam merah yang diselenggarakan di wilayah RT 03/04 Kelurahan Tamalanrea Jaya, khususnya para ibu rumah tangga memperoleh respon yang positif. Para warga masyarakat yang mengikuti pelatihan dan di akhir pelatihan memperoleh modal dan kesempatan untuk mandiri atau kelompok mengembangkan sayur brokoli dan bayam merah sebagai bahan baku olahan masakan yang sehat untuk keluarga. Oleh karena peangolahan sayur brokoli dan bayam merah pada akhirnya dapat menjadi media saling membelajarkan, berkomunikasi demi bertambahnya wawasan dan merubah paradigma berpikir dari yang tidak melakukan apa-apa menjadi dapat melakukan aktivitas bahkan memberi layanan yang lebih baik akan kebutuhan makanan sehat bagi keluarganya. Dengan melakukan aktivitas olahan sayur brokoli dan bayam merah menjadi olahan pangan tanpa mengganggu lingkungan, juga kesempatan untuk saling berbagi informasi, dan menjadi modal bagi ibu-ibu rumah tangga untuk mengembangkan usahanya untuk menunjang pendapatan keluarga. Kegiatan pengabdian pada masyarakat 
yang memberdayakan masyarakat khususnya perempuan memiliki arti bagi perubahan cara berpikir kelompok ibu- ibu peserta PPM. Tindak lanjut kegiatan ini perlu diikuti dengan pendampingan oleh tokoh masyarakat misalnya pengurus PKK khususnya pengembangan jiwa kewirausahaan dalam kegiatan yang terintegrasi dengan program kerja KWT RT, RW setempat. Hal ini digunakan untuk menjamin kelangsungan pola kegiatan yang memberdayakan kaum ibu untuk turut meningkatkan kualitas hidup melalui pola makan yang sehat dalam kebersamaan perumahan yang lebih kondusif.

\section{DAFTAR PUSTAKA}

Anonim. 2017. Resep Olahan Sayur brokoli dan bayam merah yang Gurih dan Mudah. Diakses dari kuliner.bacainfo.com pada tanggal 2 Maret 2017.

Rahmawaty, Penny., HY Agus Murdiyastomo., $\mathrm{M}$ Lies Endarwati. 2012. Pemberdayaan Usaha Ekonomi Produktif Bagi Masyarakat Miskin di Kota Yogyakarta. Universitas Negeri Yogyakarta. Yogyakarta.

Septiarti, Wisni., Mulyadi., RB Suharta. 2012. Peningkatan Kualitas Kehidupan dengan Pelatihan Kewirausahaan Budidaya Jamur Tiram yang Ramah Lingkungan di RW V Minomartani Ngaglik Sleman. Universitas Negeri Yogyakarta. Yogyakarta. 